Van Hout, Roeland and Henk Münstermann

1988 The multidimensionality of domain configurations. International Journal of the Sociology of Language 74: 107-124.

Van Hout, Roeland and Ton Vallen

1984 Sociolinguïstiek: Januskop of kop van Jut [Sociolinguistics: Janus face or scapegoat]? Tijdschrift voor Taal- en Tekstwetenschap 4: 279-286.

Van Istendael, Geert

2008 Plezier en pijn van het Nederlands [Pleasure and pain of Dutch]. Samen beleid maken in het GO! Onderwijs van de Vlaamse Gemeenschap. Beleidscahier nummer 3, 29-33. Brussel: Ministerie van Onderwijs van de Vlaamse Gemeenschap.

Willemyns, Roland

2003 Dutch. In: Ana Deumert and Wim Vandenbussche (eds.), Germanic Standardizations: Past to present, 93-125. (Impact: Studies in language and society 18.) Amsterdam: John Benjamins.

Stefan Grondelaers, Nijmegen (The Netherlands)

\title{
32. Supraregional patterns and language change
}

1. Introduction

2. Supraregional phenomena

3. Supraregional patterns defined and explained by formal criteria

4. Conclusion

5. Suggestions for future research

6. Atlases and dictionaries

7. References

\section{Introduction}

The two most important dialect groups that are traditionally recognized in the Dutch language area are Low Franconian, covering almost the whole area, and Low Saxon, located in the northeast, from Groningen to the north of Limburg. Low Franconian is usually subdivided into the traditional dialect groups of Limburgian, Brabantish, Flemish and Hollandic.

In this contribution we will focus on phenomena that are not confined to these classical dialect groups, and we do so from two perspectives. First, we approach these phenomena from a purely descriptive perspective (section 2). Our aim is to show that, in the Dutch language area, certain phenomena exist that are not confined to traditionally recognized geographical distinctions. In this sense, these phenomena are truly supraregional. We show, with examples from phonology, morphology and syntax, that certain linguistic features have more or less the same geographical distribution, albeit in a way 
that does not match any of the classic geographical distinctions just mentioned. We will discuss the following supraregional patterns. First, we will recognize a zone along the German border, running from north to south. This allows us to compare the eastern north-south zone with the effects of the Belgian-Dutch state border (which was not established until the year 1839). Secondly, we recognize a pattern that covers the whole Dutch language area. The third supraregional pattern we discuss is the northeast-southwest pattern. We would like to thank Sjef Barbiers and Ton Goeman for providing us with many instances of supraregional variation.

In the second part of this paper, we approach the phenomenon of supraregional patterning from a theoretical perspective (section 3.). Here we demonstrate that, although certain properties of dialects might seem different at first sight, on closer view these properties turn out to be manifestations of common, deeper, formal principles of grammar. In these cases the relevant formal principles create a 'supraregional pattern', crossing the borders of the traditional dialect groups. We present two examples of formal grammatical principles, one phonological and the other syntactic. The phonological principle allows us to explain the deep relation between diphthongization in hiatus position which occurs in many dialects of Brabant and Limburg dialects, on the one hand, and diphthongization under the falling tone in the dialect of Maastricht, on the other (section 3.1.). In the syntactic domain, we discuss the appearance and variation of reflexive pronouns. Formal syntactic principles allow us to uncover the common properties of various instances of reflexivization taking place in dialects across the Dutch language area (section 3.2.). In section 4. we give a short summary and in section 5. we present a perspective for further research.

\section{Supraregional phenomena}

\subsection{Political borders}

The political borders of the Netherlands coincide with natural borders hardly anywhere. The borders with Belgium and Germany cut through classical dialect areas. The border with Belgium cuts through the Limburgian dialect area, the Brabantish area, and partly also the Flemish area, because part of this area is located in Dutch Zeeland. The border with Germany runs through the Low Saxon area, the Limburgian area and the Ripuarian area (cf. Map 1.1 in chapter 1 of this volume).

Because the political borders of the Netherlands do not correspond to the borders of traditional dialect areas, differences between Dutch and Belgian varieties can only be expected to affect newer phenomena. In what follows we demonstrate that a supraregional pattern can be identified among the Dutch dialects which runs along the German border. At first sight, this might suggest that somehow the political border has been active in the creation of this supraregional pattern. Yet, on closer inspection, this is not the case at all. In fact, the superregional pattern located to the west of the border is part of a still larger dialect area in which dialects at the other side of the border also participate. The German border, then, is just what it is, a political border that happens to cut through an old, large group of dialects. 


\subsubsection{The eastern border}

From the perspective of the Dutch language area, a supraregional pattern can be identified running along the eastern border. This pattern cuts through different dialect groups: Low Saxon varieties in the north and Limburgian/Ripuarian dialects in the south. Here we list some of the instantiations of this eastern supraregional pattern:

(i) phonology

- In this eastern border zone the historical mid vowels are not raised, the way they are in SD and most other dialects of the Dutch language area. Thus, one finds words like [de:f] 'thief' and [ho:k] 'angle', rather than [dif] and [huk]. Dialects in the eastern zone that exhibit the mid realizations are Limburgian dialects, and Low Saxon dialects of Gelderland and Overijssel.

(ii) morphology

- The eastern border zone is rather broad in the case of morphological umlaut. The zone is largest in the case of umlauted diminutives (MAND I, maps 60b-63a) and of umlauted 3.singular present tense of verbs (certain classes of strong verbs MAND II, maps 53a-54a). The zone is smaller and extends to the east in the case of noun pluralisation (see MAND I, chapter 1). The strong plural forms of nouns, which end in either -e, or, after a rather early rule of schwa-apocope, in zero, follow the same pattern. There is a correlation between umlauted plurals and the strong noun class (the results of this situation for palatalisation in the singular have been explained by Postma and Van Reenen 2009).

(iii) (morpho-) syntax

- For second person singular inflection, the eastern border zone can be considered as a geographic area (e.g. du komst, 'you come', versus jij/gij komt in the rest of the language area), in particular if both complementizer agreement and verbal inflection are taken into account. In all provinces along the border except for Gelderland, we find the $-s t$ suffix (SAND I, maps 25a, b). Friesland belongs to the eastern border zone for this phenomenon. German also has this suffix and may have influenced the eastern dialects.

- The weak reflexive zich SIG and the strong reflexive zichzelf SIG SELF (cf. section 3.2.) also define the eastern border zone as a coherent area (SAND I, maps 68a69b). This time, Frisian does not belong to the area (it has HIM and HIMSELF); moreover, the standard language and various dialects in Holland also have SIG and SIGSELF. The occurrence of weak reflexives in inalienable possession constructions is also typical for the eastern border zone, with the exception of Groningen (SAND I, map 78a). An example of this construction is Hij heeft zich de handen gewassen Lit.: 'He has SIG the hands washed' / 'He washed his hands.' As in the case of the -st suffix, it is possible that German has influenced this pattern.

- The same holds for fronting in imperatives, which is relatively widespread in German but restricted to the object dat 'that' in eastern Dutch, as in Dat doe maar! 'Lit. That do just'/ 'Alright/Go ahead' (SAND I, map 95b). For this construction, the border zone consists of the small eastern part of the eastern provinces and the eastern half of North Brabant. 
From the perspective of the Dutch language area, this would seem to indicate that there is an eastern dialect zone, running along the German border. However, strictly speaking, this is not entirely correct, of course, since this 'zone' continues at the other side of the border (at least to the extent that the dialects are still used there).

\subsubsection{The southern border}

The border between the Netherlands and Belgium has been a topic of discussion for some time (see, among others, Weijnen 1966, Taeldeman 1990). This border is starting to exert a clear influence on the standard language as it is spoken on both sides of the border. Very likely, this will have important consequences for the dialects on both sides of the border, even if they belong to the same historical dialect group.

\section{(i) phonology}

- At the phonological level it is quite clear that the border influences the phonology of the standard language, although not of the dialects - at least not yet. Thus, Van de Velde (1996) observes, among other things, that the border determines the realization of diphthongs, of $/ \mathrm{r} /$ and of fricatives.

(ii) morphology

- The second person plural - $(e) t$ - as in gij breekt 'you break' - follows the border between Zeeuws Flanders, the western part of North Brabant, East Flanders and Antwerp. This can be seen on maps for the present and the past tense (MAND II, maps 55a, 59b, 61b, 62b, 65a). This is a rather recent development; the Dutch area showed $-t$ as well until around 1955. Nowadays it has the general plural ending -ə(n).

- Another case concerns the ablaut pattern vroos-gevrozen 'froze-frozen', against vroorgevroren (MAND II, map 81a), where the division follows the border of western North Brabant and Antwerp.

(iii) syntax

- The SD sentence Ik weet niet wie ze had kunnen roepen, Lit.: 'I know not who she had can.INF call.INF' has three variants in the Dutch language area: (1) with the interrogative complementizer of 'if': Ik weet niet wie of ze had kunnen roepen; (2) with two complementizers: Ik weet niet wie of dat ze had kunnen roepen; (3) with the complementizer dat 'that': Ik weet niet wie dat ze had kunnen roepen. The two variants that have the complementizer of 'if, whether' are completely absent in Belgium and occur in almost all of the provinces of the Netherlands (SAND I, map 16a).

- The infinitival complementizer van 'of' is typical for all areas in Dutch speaking Belgium and completely absent in the Netherlands (SAND I, map 18b) where the complementizer om is used, as in Het was aardig van Jan VANIOM te komen 'It was kind of John for to come'.

- For the word order in verb clusters the Belgian-Dutch border also seems to be relevant. Dutch speaking Belgium uses the order verteld heeft 'told has' very homogeneously, while the southern and central part of the Netherlands uses heeft verteld 'has told' in addition to this order (SAND II, map 14b). With modals, conversely, the only order possible in Belgium is mag zien 'may see', whereas the order zien mag 'see may' is also quite common in the Netherlands (SAND II, map 15b). 


\subsection{The entire language area}

A number of non-standard phenomena show up in the entire language area. In the domain of morphology and syntax the data appear to represent stylistic (colloquial versus formal) rather than geographical variation.

phonology

- A good example of a phonological phenomenon that occurs repeatedly in the whole Dutch language area, but in separated locations, is diphthongization in hiatus position of long high vowels. Thus, while the dialects of Bellingwolde (Lower Saxonian), Eijsden (Limburgian) and Knokke (West Flemish), for instance, are all located in a larger area where there is no diphthongization of long high vowels (northeast in the case of Bellingwolde; south-east in the case of Eijsden; south-west in the case of Knokke), they do have diphthongization in hiatus position. A representative example illustrating this is vrijen 'to court'. In the larger area there is no diphthongization, so generally this example is realized with a high vowel. However, Bellingwolde has [vręidn] (also with an epenthetic $d$ ), Eijsden has [vвæijo] and Knokke has [vre.in]. (These data were obtained from the GTRP-database available on the Meertens website: <http://www.meertens.knaw.nl/mand/database/>.)

morphology

- Nearly the whole linguistic area has the irregular weak past forms (past tense and participle) without the original final -e for zocht-gezocht 'sought-sought'. In older varieties we did find the forms zochte-gezocht. The forms without original final $-e$ look like normal ablaut verbs (MAND II, map 82a).

syntax

- Two types of long WH-dependencies seem to involve colloquial rather than dialectal Dutch and do not show a very clear geographic patterning: (i) Wat denk je wie ik in de stad heb gezien?' 'Lit. What think you who I in the city have seen' 'Who do you think I saw in the city?'; (ii) Wie denk je wie ik in de stad heb gezien? 'Who think you who I in the city have seen' (same meaning). SD would have a construction similar to English with only one WH-word which occurs in the main clause. The WHATWHO construction is found in the entire language area, but the number of locations where it occurs is considerably smaller in Belgium (SAND I, map 91a). There, the variant of the type Wie denk je dat ik in de stad heb gezien occurs more often. The same holds for the WHO-WHO construction (SAND I, map 91b).

- Double negation expressing single negation as in Nooit niet, lit. 'Never not!' 'Never!', as an answer to a question like Wanneer zal de wereldvrede komen 'When will there be world peace?', occurs in the whole language area (SAND II, map 56a). Similarly, nergens geen 'nowhere no' as in Zitten hier nergens geen muizen, lit. 'Sit here nowhere no mice?' 'Aren't there any mice here?' is common both in the Netherlands and Belgium and should be regarded as colloquial.

\subsection{Northeast-southwest}

There are various phenomena that occur in the distinct areas of Flanders and the northeast of the Netherlands (Taeldeman 2007: 100 and particularly Devos 2002). These phe- 
nomena are sometimes regarded as the result of Ingvaeonic influence (Van Bree 1987) (although this does not apply to our phonological examples).

phonology

- Phonologically, neither the dialects of the southwest nor the dialects of the northeast (with the exception of Friesland) underwent Final Schwa Loss. Thus, in these parts of the Dutch language area realizations like [bedə] for SD [bet] 'bed' occur, (with final $[t]$ as a result of Final Devoicing).

- Another phonological phenomenon shared by the southwest and the northeast is the syllabification of sonorant consonants in the peak position of the syllable. A SD word like [kø:kə(n)] 'kitchen', for instance, is pronounced as [kø:kn] in many dialects of the southwest (French Flanders, West Flanders, Zeeland Flanders) and also in many dialects of the northeast (in the Dutch provinces of Groningen, Drenthe and Overijssel and a small part of Gelderland). The phonological environment where syllabic consonants are allowed is more general in the southwest than in the northeast. In words like (SD) [molə(n)] 'windmill', for instance, where a lateral precedes the nasal, a syllabic version of the nasal is much more widespread in the southwest than in the northeast. In the southwest, this is as widespread as the syllabic nasal in a word like [kø:kn]. In the northeast, however, a syllabic consonant following a lateral only occurs in Groningen and in a few dialects in Drenthe (GTRP-database, accessible at the Meertens website, at www.meertens.knaw.nl/mand/database/, cf. Goeman and Taeldeman 1996).

\section{morphology}

- In origin, the vowel schwa is a nominal class indicator, and therefore it can show up with certain adjectives in predicative function, like for instance nieuwe 'new'. This schwa is present in the southwest: West and East Flanders and Zeeland, and in the northeast: Drenthe, Overijssel, Achterhoek, southeast Groningen, and Veluwe. This regional distribution is mainly the effect of schwa apocope in the other regions (MAND I, map 66a; MAND II, map 26b).

syntax

- A finite complementizer following a relative pronoun (e.g. de man die dat ik zag 'Lit. the man REL that I saw') occurs in subject relatives, object relatives and free relatives in Friesland. In the southwest, this phenomenon is common in an area consisting of Zeeland, western Antwerp and the northeastern part of East Flanders (SAND I, maps $16 \mathrm{~b}, 84 \mathrm{a})$.

- In syntactic environments in which SD has SIG (e.g., inherently reflexive verbs), the weak reflexive hem 'him' is found in Friesland and the western part of Groningen, and in a southwestern area consisting of Flanders (i.e., French, West and East Flanders) and Flemish Brabant (SAND I, maps 68a,b).

- Friesland and the southwest, i.e. French, West and East Flanders, also share the property of having HAVE as the perfective auxiliary with geweest 'been'. In Flanders, this property seems to correlate with HAVE as the auxiliary of gevallen 'fallen' and tegengekomen 'encountered', which have BE in Frisian (SAND II, map 40a).

So far we have established, on purely descriptive grounds, that supraregional patterns do exist in the Dutch language area. We will now show that it is also possible to relate areas by means of formal principles of grammar, although these areas seem to be distinct on the surface. The various dialect groups can then be seen as instantiations of a deeper, unifying formal principle. 


\section{Supraregional patterns defined and explained by formal criteria}

One of the tasks of linguistic theory is to provide explanations for the fact that certain linguistic phenomena appear to not to be related to geographical or diachronic factors, in the sense that they appear over and over again, both in time and in space.

In this contribution we have provided examples of two Dutch supraregional phenomena, that is, processes which appear in various, non-contiguous regions of the Dutch language area. One example, diphthongization, is phonological in nature and the (re)emergence of reflexive pronouns in Dutch varieties around 1600 is a morphosyntactic process. We will argue that these two cases provide a better understanding of the phenomenon at hand if we rely on principles of formal grammar.

In the next section, we will sketch an analysis of diphthongization based on formal phonological principles.

\subsection{Diphthongization}

Diphthongization of long vowels is a frequent process, which many dialects have undergone in the Dutch language area. The area where diphthongization has applied is situated in between two areas where the process did not apply: the southwest and the east (cf. section 2.3. above). Thus, in the latter two areas we still find original pronunciations like [i:s] 'ice', whereas in the intervening area diphthongal realizations such as [cis] are attested (Weijnen 1966: 214-217).

It is possible to explain why diphthongization has taken place by invoking principles of formal phonology. There is a phonological constraint requiring that the head of a prosodic constituent must be more sonorous than a high vowel (Harris 1994, 1997)). Let us call this constraint the Head Condition. Consider the representation of the long vowel [i:].

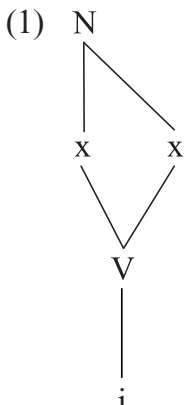

$\mathrm{N}$ is the nucleus, the core of the syllable. The $\mathrm{x}$-slots are the terminal elements of syllable structure. A long vowel has two such x-slots. The x-slots are linked to the root node (here V), which expresses the basic unity of the segment, since it dominates all features that are linked. The first $\mathrm{x}$-slot is the head of the nucleus and the second its dependent. In (1) the Head Condition is not satisfied because the head $\mathrm{x}$-slot is a high vowel. The following representation contains a diphthong: 
(2)

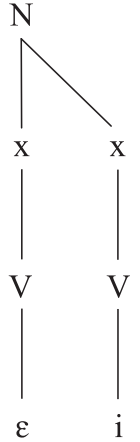

In this representation the first $\mathrm{x}$-slot vowel is more sonorous than a high vowel. The Head Condition is therefore met. Notice that a diphthong has a root node in the dependent position which is not connected to the head. This aspect of a diphthong is also very important, as we will show now.

It has been observed repeatedly that diphthongization is favored in so called hiatus positions (Van Bree 1987, Draye 2002, Swets 2004). Hiatus is the environment where a vowel is immediately followed by another vowel and where the two vowels can be separated by a homorganic glide (e.g. in items such as dieet 'diet', etc.). We can observe this tendency in the dialect of Kerkrade, and in many dialects in the transitional zone between the Ripuarian and East Limburgian dialects as well. The following data are taken from the Kirchröadscher Dieksiejoneer (1987).

(3) word internal position; no diphthongization in Kerkrade

$\begin{array}{llll}\text { [i:]s } & \text { 'ice' } & \text { [i:]ver } & \text { 'diligence' } \\ \mathrm{jr}[\mathrm{i}:] \mathrm{s} & \text { 'grey' } & \text { [i:]zer } & \text { 'iron' } \\ \mathrm{h}[\mathrm{u}:] \mathrm{s} & \text { 'house' } & \mathrm{b}[\mathrm{u}:] \mathrm{se} & \text { 'outside' }\end{array}$

In hiatus, however, Kerkrade does show diphthongization.

(4) hiatus; diphthongization in Kerkrade

b[zjə] 'bee, pl.'

$\mathrm{kn}[\varepsilon j \mathrm{j}] \quad$ 'kneel, inf.'

$\mathrm{b}$ [owə] 'build, inf.'

r[owə] 'rough, attr. masc.'

The contrast between (3) and (4) demonstrates that hiatus favors diphthongization (cf. also our remarks in section 2.2.).

Something similar happens in the dialect of Tilburg. In this dialect lower mid vowels are diphthongized, but only in hiatus position. This is shown in (5) and (6) (examples from Swets 2004).

(5) word internal position; no diphthongization in Tilburg

$\mathrm{d}[\varepsilon:] \mathrm{k} \quad$ 'dike'

$\mathrm{h}[œ:] \mathrm{s}$ 'house'

r[œ:]te 'window' 
(6) hiatus; diphthongization in Tilburg

bl[cjə] 'glad, attr.'

1[œjə] 'lazy, attr.'

r[œyə] 'to moult'

Why is the hiatus position special? Consider the following two words of the Kerkrade dialect. The form in (7a) (cf. also (3)) has a long high vowel in preconsonantal position; the form in (7b) (cf. also (4)) contains a hiatus.

(7) word-internal position hiatus position
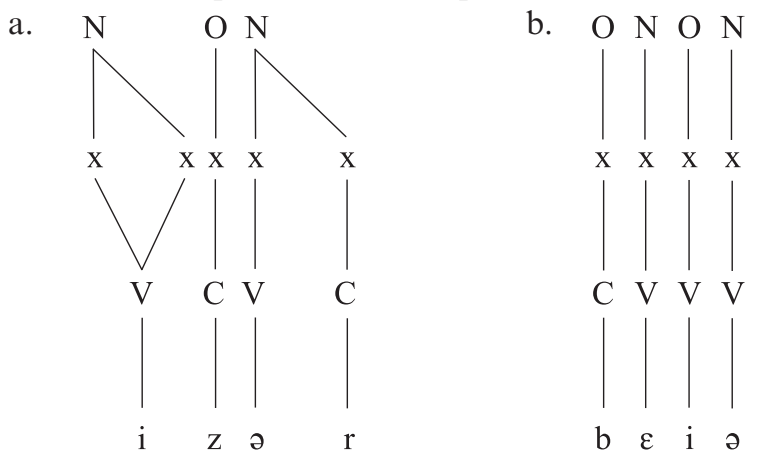

The $\mathrm{O}$ in (7) denotes the syllable onset, a position containing a prevocalic consonant or glide. In this position a high vowel is phonetically realized as a glide. The form [i:zər] does not undergo diphthongization; the form [bejə] does. Why should these cases differ?

In (2), we showed that diphthongization creates a segment (root node) that is only located in the dependent position of a nucleus. Apparently, then, some languages do not seem to allow this configuration. In these languages a dependent position of a nucleus is not strong enough to license a highly sonorous segment, like a vowel. We will call this the Dependent Condition. Basically, it requires that IF a vocalic root node is attached to the dependent position of a nucleus, that vocalic root node must ALSO be linked to the head position of the nucleus.

The dialect of Kerkrade is obviously a system where the Dependent Condition takes effect. Because of this, it is not possible to diphthongize the high vowel in the configuration in (7a). If that would have happened, an independent vocalic root node would be created in the nuclear dependent, conflicting with the Dependent Condition. Things are entirely different, however, when the vowel is located in hiatus position, as in (7b). In this case, applying diphthongization, fulfilling the Head Condition, does not lead to a situation where a vowel is located in a dependent position in the nucleus. This time, the vowel created after diphthongization occupies the onset position. This does not conflict with the Dependent Condition, for the simple reason that the independent segment, newly created by diphthongization, does not occupy a nuclear dependent position. It occupies the onset of the post-tonic syllable, where it is phonetically realized as a glide.

To summarize, the hiatus position favors diphthongization since a hiatus can contain an onset. For this reason, the second half of the diphthong does not occupy a dependent position in the nucleus. Rather, it occupies the onset position. As a result, diphthongization, triggered by the Head Condition, does not lead to a violation of the Dependent Condi- 
tion. We will now motivate our account of the hiatus effects, based on the principles of formal phonology (the Head Condition and the Dependent Condition). We will show that this account can also explain Maastricht Diphthongization.

\subsubsection{The effects of hiatus on diphthongization in Maastricht}

Most Limburg dialects show a curious phenomenon. Words either have a so-called Accent 1 or an Accent 2. Accent 2 is usually found in stressed syllables with a long high vowel, whereas Accent 1 is found in two environments: it is found in stressed syllables with a long mid, or a long low vowel. Secondly, it is attested in words with a long high vowel that historically have lost a schwa. Some examples from the dialect of Roermond are given in (8), taken from Kats (1985). To illustrate the phenomenon of Schwa Drop we have added the corresponding German forms.

(8) Mid and low vowels have Accent 1

$\begin{array}{llll}\text { d[e: } 1] \mathrm{f} & \text { 'thief' } & \mathrm{r}\left[\mathrm{o:}{ }^{1}\right] \mathrm{t} & \text { 'red' } \\ \mathrm{d}[\mathrm{e}: 1] \mathrm{n} & \text { 'to serve' } & \mathrm{b}\left[\mathrm{o}::^{1}\right] \mathrm{t} & \text { 'boat' } \\ \mathrm{sj}\left[\mathrm{0}:{ }^{1}\right] \mathrm{p} & \text { 'sheep' } & & \\ \mathrm{r}\left[\mathrm{o}:{ }^{1}\right] \mathrm{t} & \text { 'council' } & & \end{array}$

High vowels have Accent 2

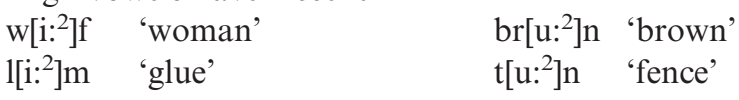

High vowels have Accent 1 iff Schwa Drop has applied

$\begin{array}{ll}\text { Roermond } & \text { German } \\ \int\left[i:{ }^{1}\right] \mathrm{f} \text { 'disk' } & \text { Scheibe } \\ \operatorname{pr}\left[\mathrm{u}:{ }^{1}\right] \mathrm{m} \text { 'plum, sg,' } & \text { Pflaume }\end{array}$

Jongen (1972) already pointed out that the basic phonetic difference between the two accents is one of timing. In Accent 1, the pitch switch induced by a sentence melody is located within the stressed syllable, while in the case of Accent 2 the switch is located after the stressed syllable. This can be illustrated with question intonation, with the words [pa:tər] 'father' and [wa:tər] 'water'. In question intonation, the sentence melody contains a rise.

(9) Accent 1 (early rise) Accent 2 (late rise) interrogative intonation
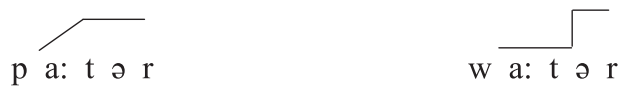

We propose that, phonologically, the difference between the two accents is one of syllable structure: vowels with Accent 1 project two nuclei, whereas vowels with Accent 2 are dominated by just one nucleus. This is illustrated in (10). 
(10) the representation of Accent 1

the representation of Accent 2
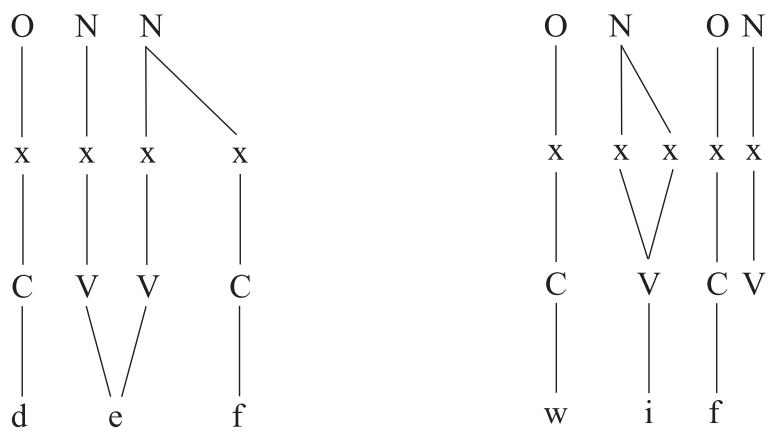

Notice that a word like [wi:f] 'wife' must have one phonetically inaudible syllable. This is a result of the fact that superheavy syllables are not possible. The consonant following the long [i:] must therefore occupy the onset position of a so called 'empty syllable'.

There is one exception to the fact that long high vowels favor a branching nucleus (i.e. favor Accent 2). If a schwa has been dropped, the high vowel must receive two syllables. Thus, a word like [ $\left.\mathrm{i}^{1}{ }^{1} \mathrm{f}\right]$ 'disk' has the following representation in the synchronic phonology:

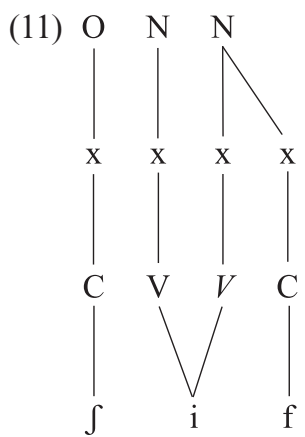

In the synchronic phonology, the schwa that was lost is still present, in the form of an abstract root node V. All non-derived words with a lost schwa are feminine, so the empty $\mathrm{V}$ has the status of a morpheme, marking feminine gender. Being a morpheme, it must be filled. In order to be filled it is moved to the left of the consonant, because there it can be filled by spreading the vowel. In this analysis the gender marker becomes an infix, so to speak. In (11) the gender marker is italicized.

We can now take the next step and relate the phonology of the accents to the segmental effects we have discussed in the previous section. There we established that diphthongization tends to occur in hiatus position. We explained this on the basis of the hypothesis that in hiatus the segment created by diphthongization is allowed in the onset position. If this analysis is valid, we make an important prediction. It is predicted that high vowels with Accent 1 tend to undergo diphthongization more readily than words with Accent 2. This follows from the very nature of the two accents: Accent 1 consists of two adjacent nuclei, the defining property of hiatus. In this position it should be possible to create a diphthong, because the second element of the diphthong appears in 
the head position of the nucleus, and not in a dependent position. Therefore it does not violate the Dependent Condition.

This prediction is borne out for the diphthongization process in the dialect of Maastricht, which has been widely studied (Goossens 1956, Gussenhoven and Aarts 1999). The Maastricht data in (12) are taken from Endepols (1955).

(12) Maastricht diphthongization under Accent 1 only

bl[ $\left.\varepsilon^{1}{ }^{1}\right]$ f 'stay, 1st p. sg.' bl[i: $\left.{ }^{2}\right] \mathrm{ve} \quad$ 'to stay'

$\mathrm{d}\left[\mathrm{ou}^{1}\right] \mathrm{f} \quad$ 'pigeon, sg.' $\quad \mathrm{d}\left[\mathrm{u}:{ }^{2}\right] \mathrm{ve} \quad$ 'pigeon, plur.'

These examples show that high vowels with Accent 1 diphthongize, whereas high vowels with Accent 2 do not.

To explain the affinity of diphthongization with hiatus position, we might try to find an explanation in terms of surface phonetic facts, as in many functional approaches. Whether such an explanation is successful or not is not at stake here. The important thing is that such an explanation cannot possibly be related to the fact that in Maastricht Accent 1 triggers diphthongization. To explain Maastricht diphthongization in terms of surface phonetics, we would need an entirely different, unrelated explanation, one that is based on the surface phonetics of Accent 1. An account based on principles of formal phonology, however, immediately relates the affinity of diphthongization with hiatus in a non-tonal dialect to the fact that in Maastricht diphthongization applies only under Accent 1. In terms of the abstract principles of formal phonology, both phenomena are identical. This is a result of the fact that the structure of Accent 1 itself requires a hiatus position.

In this section, we have tried to explain a supraregional phonological pattern in terms of principles of formal phonology. This pattern involves the tendency for diphthongization to occur more readily in hiatus position. We saw that this phenomenon is active in two separate areas: first, in the dialect of Kerkrade and the transitional zone between Ripuarian and East Limburgian, as well as in some dialects of Brabant. The analysis in terms of principles of formal phonology we have proposed can be independently motivated on the basis of Maastricht diphthongization. These principles make it possible to relate this process to the phonology that generally applies in hiatus. No such explanation is possible in an analysis using functional principles based on surface phonetics, for the simple reason that, phonetically, a vowel with Accent 1 does not contain a hiatus at all.

Summarizing, the two principles of formal phonology introduced above, the Head Condition and the Dependent Condition, can be instantiated in various ways across the classical dialect areas. In Brabant and Limburg, these two interacting principles account for the fact that there are many dialects where diphthongization only applies in hiatus position. The same principles also explain why in Maastricht only Accent 1 allows diphthongization. Different phenomena, then, find a uniform explanation under these two principles. In this sense, these formal principles are truly supraregional, not in the traditional, purely descriptive way, but in a more abstract, theoretical sense.

\subsection{The case of reflexives}

A similar situation holds with regard to changes in the morphosyntactic properties of language varieties. Changes can be restricted by general grammatical patterns to a large 
extent, i.e. they do not necessarily exclusively depend on functional considerations or regional and/or analogical properties. In this section, we will restrict our discussion to the (re-)emergence of reflexive pronouns in Dutch varieties around 1600, although several other examples of the grammatical role in language change can be provided for the Dutch language area, such as the gradual but persistent reduction of verbal inflection in varieties of Dutch (cf. Bennis and MacLean 2007), or the variation in word order within verbal clusters in Dutch dialects (cf. Barbiers 2008, Bennis 2009, Barbiers and Bennis 2010).

Most varieties of Middle Dutch did not have reflexive pronouns. With the exception of southeastern varieties, coreference between a pronominal element and a c-commanding antecedent within the same clause was expressed by a personal pronoun (cf. Van Loey 1969, Schönfeld 1959, Van der Sijs 2004, Van der Horst 2008). In (13) we observe that the personal pronouns hen 'them' and hem 'him' refer to the clause subjects, $s i$ 'they' and die here 'the lord', respectively.

(13) a. Sere begonsten si hen vervaren Very much began they them(selves) to fear

b. Die here riep te hem twee knapen

The lord called towards him(self) two boys

According to Van der Horst (2008), Old Dutch already allowed the possibility of personal pronouns in binding contexts, although a reflexive 3 rd person pronoun sig was also found in the Wachtendonckse Psalmen (written in an eastern variety of Old Dutch, around the tenth century). The reflexive pronoun sig was originally used to express reflexivity for all person, number, and gender combinations in Sanskrit and Old Germanic. In Gothic, the reflexive pronoun sig was replaced by a personal pronoun in first and second pronoun contexts. This situation is similar to what we observe in presentday SD and other Germanic languages. In Middle Dutch, the development went so far as to replace a reflexive by a personal pronoun for third person contexts as well. This resulted in a Middle Dutch grammar in which reflexivity was no longer lexically expressed. The same situation still obtains in Afrikaans (cf. Ponelis 1979), as illustrated in (14). In an inherent reflexive construction such as in (14a), the pronoun hom obligatorily refers to the subject of the clause Cilliers. In the construction in (14b), the pronoun hom may but does not necessarily need to refer to Oom Andries.

(14) a. Cilliers kwyt hom goed van sy taak. Cilliers acquits him well of his task

b. Oom Andries jaag 'n dosyn donkies voor hom uit. Uncle Andries rushes a dozen donkeys before him

In most theories on binding (e.g. Chomsky 1995, Reuland 2001), a distinction is made between coreference and binding. Coreference obtains if two nominal phrases happen to refer to the same extralinguistic person or object. This implies that there are two reference relations between linguistic objects and the same extralinguistic person or object. In binding, the situation is different in such a way that there is just one reference relation, which relates the antecedent-anaphor pair to the extralinguistic person or object. It is 
clear that for first and second person contexts it does not make any difference in interpretation whether the relation between antecedent and pronominal is made within the grammar (binding) or in interpretation (coreference). The pronouns uniquely refer to speaker or addressee in all cases. A special form for reflexivity is interpretively superfluous in those cases. However, in third person contexts there is a clear difference. The intralinguistic binding relation forces the pronominal/reflexive to be identical in reference to its antecedent. However, a third person pronoun is of course often used in cases in which a potential antecedent is not interpreted as referring to the same extralinguistic person as the pronoun. A specialized reflexive pronoun thus functions to mark reference by binding, whereas the third person personal pronoun may show up as coreferential, but only in cases in which binding is impossible. This situation is illustrated in (15) and (16).

(15) a. Ik zie mij dat wel doen.

I see me that PART do

'I consider myself able to do that'.

b. Hij ziet mij dat wel doen.

He sees me that PART do

(16) a. Hij ziet zichzelf $_{i}$ / *hem he $_{i}$ dat wel doen.

$\mathrm{He}$ sees REFL that PART do

'He considers himself able to do that'.

b. Hij $j_{i}$ ziet $*_{z i c h z e l f} /$ hem $_{j}$ dat wel doen.

$\mathrm{He}$ sees REFL / him that PART do

c. Ik zie hem/*zichzelf dat wel doen.

I see him/ REFL that PART do

d. $\mathrm{Hij}_{i}$ denkt dat ik hem $/$ *zichzelf $_{i}$ zie.

He thinks that I him / REFL see

In (15), the first person pronoun mij is used in a coreferential (15a) and a non-coreferential context $(15 b)$. In $(16 a, b)$ we observe that a reflexive pronoun must be used in a third person reflexive context, whereas a non-reflexive context requires a personal pronoun. In (16c), we encounter a familiar and logical restriction to binding relationships. A reflexive pronoun must be bound. Moreover, it must be bound in a strict local context. It is syntactically impossible to establish binding across a finite sentence boundary. This accounts for the unacceptability of the reflexive pronoun zichzelf in (16d). In those cases, coreference can be established by only using a personal pronoun, just like in (15a).

By extending the use of personal pronouns from first and second person to third person reflexive contexts in Old and Middle Dutch and Afrikaans, these languages gave up a lexical distinction between reflexive and non-reflexive third person pronominals, i.e. the difference between (16a) and (16b) can no longer be expressed. The advantage is that the grammatical feature [ \pm reflexive] is no longer required within the grammar of those languages, which implies that these languages no longer have reflexive pronouns. On the other hand, these languages are no longer able to encode third person coreference/binding relations lexically, thus creating an ambiguity between reflexive and non- 
reflexive contexts, as seen in $(14 b)$ or $(16 a, b)$. This is not a very consequential loss of interpretative possibilities, since the extension of this ambiguity problem is relatively small, due to the fact that many of the constructions in which third person reflexives show up are inherent reflexive constructions in which the reference of the pronoun is established by the reflexivity of the predicate, independent of the lexical properties of the pronoun. This is demonstrated in (17).

(17) a. Hij vergist zich /*mij.

He is-wrong himself / me.

b. Hij herinnert zich / *mij dat niet.

He remembers himself / me that not

The inherently reflexive verbs vergissen (17a) and herinneren (17b) require a coindexed pronoun. It thus follows that in these cases, reflexivity is a result of lexical properties of the verb rather than properties of the pronoun. A reflexive pronoun is relatively superfluous in (17), which might be the reason why many dialects of Dutch, especially the dialects in the northern area (Friesland and surrounding areas) and Flanders allow the occurrence of the non-reflexive pronoun hem in these circumstances (cf. 2.3.iii). (These areas do have special anaphors in constructions of the type in [16]: in Friesland the 'strong anaphor' is hemzelf and in Flanders zijnzelve [West Flanders] or zijn eigen [East Flanders, Brabant].)

Interestingly, from the fifteenth century on, reflexive pronouns were reintroduced in some varieties of Dutch. This reintroduction was clearly influenced by the fact that German kept its reflexive third person pronoun throughout its history. The return of reflexives started in the eastern regions of the Dutch language area, bordering Low and High German-speaking areas. In the fourteenth and fifteenth century, the forms sich and sick are found in official documents in eastern areas, such as Gelre and Drenthe (cf. Postma 2004, 2012). Apparently, varieties of Dutch were generally ready for the return of reflexives. The reintroduction of reflexive pronouns proceeded relatively fast - so fast that the Dutch writer P. C. Hooft changed pronouns into reflexives when he revised his texts for later editions (Van der Wal 1992). However, the different varieties did not agree on the actual form of the reflexive pronoun. There were essentially three varieties: reintroduction of the form zichzelf, adding a reflexive marker self to a personal or possessive pronoun (hemzelf 'himself' or zijnzelve 'hisself'), and the development of a construction with the possessive marker eigen 'own' and a possessive pronoun, in zijn eigen 'his own'.

In the seventeenth century, when the Dutch standard language started emerging, the eastern form zichzelf gradually developed into the standard reflexive pronoun. However, Dutch dialects generally kept their reflexive forms until today, showing an interesting distribution. As is shown on Map 32.1 (cf. Barbiers et al. 2005, map 69b), only modern dialects in the area bordering the German language systematically use the Indogermanic pronoun sig in zichzelf.

The area in which dialects use zichzelf on this map does not really correspond to any traditional dialect area. We find zichzelf in most of the Saxon area, the eastern part of the Limburg area (Dutch Limburg) and the eastern border of the north Limburg/Brabant/river areas. The reflexive pronominal z'n eigen 'his own' is dominant in the Dutch 


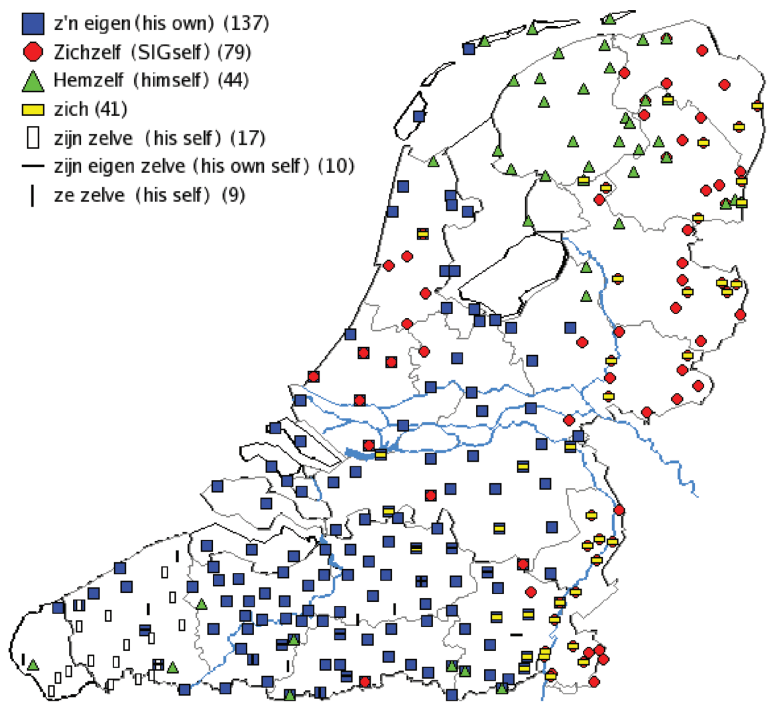

Map 32.1: Strong reflexive pronouns in dialects of Dutch

dialects and is found in Holland, Brabant, the northeast of East Flanders and Belgian Limburg, whereas West Flanders dialects opt for zijnzelve and Frisian dialects for hem$z e l f$. It is remarkable that the eastern form made it into the standard language since most dialects ended up with $z^{\prime} n$ eigen, even the dialects spoken in the areas which were politically central in the seventeenth century, i.e., the former counties of Holland and Brabant, in particular Antwerp. (It is well known that there were various instances of eastern influence on the developing standard language, cf. Boyce Hendriks 1998.)

What we observe, is that within a few centuries the reflexive pronoun was reintroduced. It received a similar structure in all the dialects: a pronominal element followed by an intensifier, as is schematically represented in (18).

(18) structure of the reflexive pronouns in varieties of Dutch:

PRONOUN \{hem, zijn, zich $\}$ + INTENSIFIER \{zelf, eigen $\}$

(Example [18] predicts that we may also find the reflexive form zich eigen. However, this form does not seem to occur anywhere in the language area [cf. Map 32.1]. A possible explanation for this fact is given in Barbiers and Bennis [2003], where it is argued that zich and eigen cannot be combined since both are marked as possessive elements.) It is reasonable to claim that the intensifier forces the pronominal to acquire a reflexive interpretation, just like in (19b) the eigen, 'own', element forces the possessive pronoun to refer to the subject of the clause (cf. Reuland 2009).

(19) a. $\mathrm{Jan}_{i}$ heeft $z i j n_{i / j}$ boeken weggegooid.

John has thrown away his books

b. Jan ${ }_{i}$ heeft $z_{i j n_{i}{ }^{* j} j}$ eigen boeken weggegooid. John has thrown away his own books 
It is remarkable that the different strong reflexive pronouns all have the same structure, as shown in (18). This must be due to the grammatical structure of reflexivity. In order to explain this grammatical property of strong reflexives, we may regard the intensifier as a reflexifier, which turns a non-reflexive predicate into a reflexive one. This is often analysed as the result of a movement operation, moving the intensifier to the verb, creating a reflexive verb. In this way the resulting verb acquires a status similar to an inherent reflexive verb. This parallellism is shown in (20).

$\begin{array}{llll}\text { (20) a. Jan kent zich-zelf } & \rightarrow & \operatorname{Jan}_{\mathrm{i}}\left[\text { zelf }_{\mathrm{j}} \text {-kent }\right] \text { zich }_{\mathrm{i}} t_{\mathrm{j}} \\ \text { John knows him-self } & & \\ \text { b. Jan vergist zich } & \rightarrow & \operatorname{Jan}_{\mathrm{i}}[\text { inh.refl vergist }] \text { zich }_{\mathrm{i}} \\ \text { John is mistaken } & & \end{array}$

The analysis in (20) thus assimilates the structural representation of inherent and noninherent reflexive constructions by assuming that inherent reflexive verbs have an implicit reflexive marker, whereas other verbs require SELF to turn the verb into a reflexive one. An analysis along these lines also explains the locality requirement on reflexivization ('Condition A').

The reappearance of Dutch reflexive pronouns shows that the choice of the actual intensifier or pronoun differs across varieties but the structure remains the same, as it is determined by the grammatical properties just described. What is also relevant for our purposes is that it is not a gradual development of different reflexive pronouns in distinct varieties of Dutch, but rather an immediate introduction of a similar reflexive structure of the type in (18) in all varieties of Dutch. Moreover, the different instantiations of reflexive pronouns should not be taken as instantaneous processes of borrowing reflexive pronouns from neighbouring language varieties. This is shown by the fact that Dutch zichzelf is structurally different from the German reflexive pronoun sich(selbst), just like hemzelf is different from English himself. In addition, the reflexive zijn eigen is not found in any other Germanic varieties. What we observe is that the reflexive structure in (18) was reintroduced and lexically realized by making rather incidental use of existing pronouns and intensifiers. What has happened is a change in grammatical structure independent of the lexical realization of this phenomenon. This change is determined by grammatical principle, not by analogy or by language contact and only superficially related to the dialectological situation of that period.

As argued above, the intensifier zelf is absent if the predicate itself forces a reflexive interpretation of the pronominal element, as in inherent reflexives, shown in (21). The distribution of the so-called weak reflexive pronouns in sentences such as (21) is shown on Map 32.2, which is taken from SAND-I, map 68a.

(21) Jan herinnert zich / hem / z'n eigen dat verhaal wel. John remembers himself that story AFFIRM

Again, we can observe that the distribution of anaphors is not really bound to traditional dialect boundaries. It is clear that the pattern differs from the one we saw on Map 32.1. We can establish that the zichzelf area on Map 32.1 (eastern varieties) corresponds to a zich area on Map 32.2, just like the hemzelf area on Map 32.1 (Friesland) gives rise to hem on Map 32.2. However, the zijnzelve area on Map 32.1 (West Flanders) is turned 


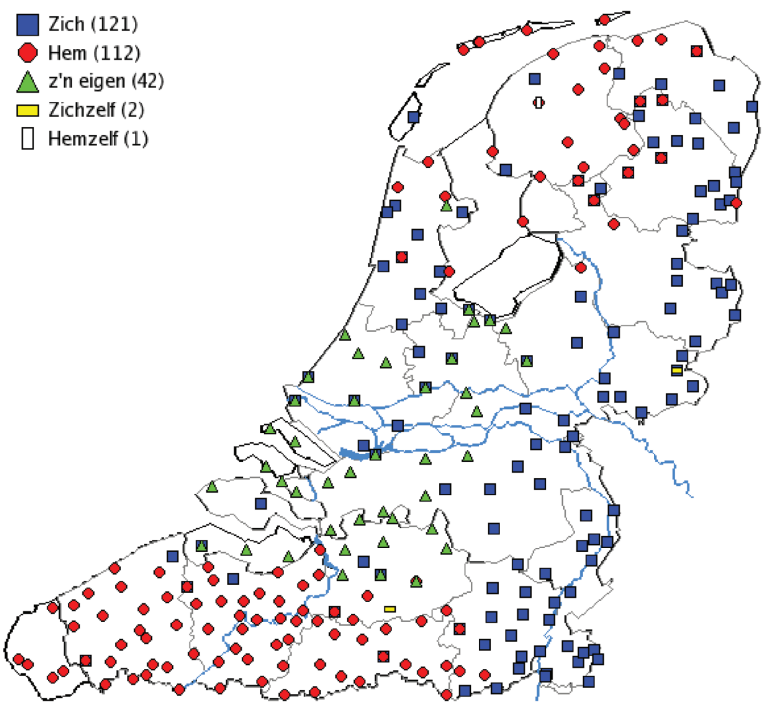

Map 32.2: Weak reflexive pronouns in dialects of Dutch

into a hem area on Map 32.2. Moreover, it turns out that the intensifier cannot be left out if the pronoun is zijn in (18). The weak alternative of the reflexive pronouns zijn eigen and zijn zelve are hem in the Belgian provinces of East Flanders and Brabant, and zich in Belgian Limburg and the Netherlands. Although several varieties keep the strong anaphor $z$ 'n eigen in weak contexts $(n=42)$, we observe a sharp reduction from the 137 occurrences of $z$ 'n eigen in strong contexts (Map 32.1). This might in part be due to the fact that the insertion of $z^{\prime} n$ eigen in (21) gives rise to a double encoding of reflexivity: both the predicate and the intensifier eigen require the pronominal element to refer back to the subject Jan.

Without going into the fascinating details of binding theory and anaphora in Dutch, we have observed that the revival of reflexive anaphors in the history of Dutch was governed by a number of principles:

- strong reflexive contexts require a grammatical structure in which a pronominal element is directly followed by an intensifier;

- the distribution of the various lexical realizations of the strong reflexive structure does not strictly correspond to traditional regional dialect boundaries, although the actual distribution should be relatable to the sociolinguistic situation of the relevant period;

- the realization of the different strong reflexive expressions in the Dutch language area is only superficially determined by copying strong reflexives from other languages. The use of zichzelf differs from the German anaphor sichselbst, just like Frisian himsels differs from English himself in grammatical properties;

- weak reflexive contexts allow the intensifier to be dropped, partly due to the fact that the reflexive nature follows from other properties of the structure;

- the strong reflexive expressions zijn eigen and zijn zelve do not have a weak variant. Dialects that use zijn eigen or zijn zelve either make use of zich or hem or use the 
strong reflexive expression in a weak reflexive context. The latter option is dispreferred for reasons of economy: the reflexive nature of the construction is expressed more than once.

The principles mentioned above indicate that language change is in important ways directly determined and restricted by general grammatical structures. The fact that all dialects have opted for a similar structure although the actual realizations are substantially different, strongly suggests that general grammatical principles determine language change. Moreover, we have demonstrated that the reintroduction of anaphors was not a gradual process determined by regional properties of the variety in question, but rather an instantaneous process with supraregional properties across the whole language area.

\section{Conclusion}

In the first part of this article we approached the phenomenon of supraregional patterns in a fairly traditional way. We presented descriptive evidence that linguistic features of a phonological, morphological and syntactic nature sometimes have a geographical distribution that transcends the traditional dialect distinctions. We referred to patterns of this type as 'supraregional'. We identified three such patterns: an eastern zone, running along the German border from the north to the south of the Dutch language area, crossing several major dialect boundaries. A second supraregional pattern is the one that essentially covers the whole Dutch language area. A third supraregional pattern consists of two disconnected areas, one in the southwest and the other in the northeast.

In the second part, we approached the question from a theoretical perspective. Our idea is that it is possible to relate superficially different phenomena, like diphthongization under Accent 1 and diphthongization in hiatus position, to each other through principles of formal grammar. This makes it possible to regard these phenomena as instantiations of governing principles. In this approach the application of abstract principles of formal grammar gives rise to a certain supraregional pattern. We gave two examples of this approach. One is a phonological example, in particular diphthongization. We showed that the Dependent Condition can relate two phenomena that, phonetically, do not have anything in common: the fact that diphthongization preferably takes place in hiatus position across dialects, and the fact that diphthongization preferably takes place in words with Accent 1 in the dialect of Maastricht. The other is a syntactic example. We showed that, across dialects, one and the same formal principle governs the distribution(s) of reflexives: the principle that strong reflexives require a grammatical structure in which a pronominal element is directly followed by an intensifier.

\section{Suggestions for future research}

One of the oldest tasks of dialectology is to define what criteria determine whether a group of language varieties constitutes a coherent group. The classical example, of course, is the division of German dialects into Middle Franconian, Rhenic Franconian, East Franconian, Upper German, etc., depending on how, in various positions (Inlaut, 
Anlaut, Auslaut) the consonants $\mathrm{p}, \mathrm{t}, \mathrm{k}$ behave with respect to the High German Consonant Shift (cf. Braune and Reiffenstein 2004). These well-known criteria are strikingly heterogeneous. For instance, the High German Consonant Shift is considered to be responsible for a crucial difference between all High German dialects and all other related dialects. Of course, this is a phonological criterion. True enough, it is an important criterion because, being closely related to the laryngeal system it is deeply entrenched in the grammatical system. On the other hand, the crucial difference between Low Franconian and Saxonian dialects is usually said to be Uniform Plural; Saxonian dialects either have $-t$ or $-e n$ in all forms of the plural, while Low Franconian dialects allow more variation in the plural (Bloemhoff 2008: 102-104). This is a morphological criterion which is not clearly related to the phonological criterion of the High German Consonant Shift. At least, there is no obvious grammatical relation between the two criteria. It thus seems to be rather arbitrary to divide the language area in dialect groups on the basis of heterogeneous criteria such as these.

Another approach is taken in the work of, among others, Nerbonne and Heeringa (e.g. Heeringa 2004; see also ch. 33 in this volume). They try to define differences between groups of dialects in terms of the objective criterion of Levenshtein distance. The problem with this approach, in our view, is that the measure is based purely on surface structure; in Heeringa's (2004) approach, grammatical properties are ignored. Clearly, this is unwarranted, for the simple reason that there is no limit to phonetic variation.

In our view, the question whether sets of language varieties constitute systematic groups of dialects is not a crucial issue. Such an approach generally boils down to historical reconstruction rather than linguistic observation. From a synchronic linguistic perspective, it is much more interesting to study inherently related phenomena and their variation in a particular language area. Careful observation of these phenomena will enhance our understanding of the deeper linguistic principles behind the superficial differences, and, consequently, will demonstrate aspects of the nature of our linguistic knowledge. We hope that work along these lines will gain in prominence in the coming years.

\section{Atlases and dictionaries}

$\mathrm{SAND} \cdot \mathrm{KD}$

\section{References}

Barbiers, Sjef

2008 Werkwoordclusters en de grammatica van de rechterperiferie [Verbal clusters and the grammar of the right periphery]. Nederlandse Taalkunde 13: 160-188, 193-197.

Barbiers, Sjef and Hans Bennis

2010 De plaats van het werkwoord in zuid en noord [The position of the verb in south and north]. In: Johan De Caluwe and Jacques Van Keymeulen (eds.), Voor Magda, Artikelen voor Magda Devos bij haar afscheid van de Universiteit Gent, 25-42. Ghent: Academia Press. 
Barbiers, Sjef and Hans Bennis

2003 Reflexives in Dutch Dialects. In: Jan Koster and Henk van Riemsdijk (eds.), Germania et alia: a Linguistic Webschrift for Hans den Besten, 25-44. Groningen: Universiteit Groningen.

Bennis, Hans

2009 Scheidbaar samengesteld werkwoord of toch niet? [Separable compound verb or not?] In: Ronny Boogaart, Josien Lalleman, Marijke Mooijaart and Marijke van der Wal (eds.), Woorden Wisselen, 15-27. Leiden: Stichting Neerlandistiek Leiden.

Bennis, Hans and Alies MacLean

2007 Variation in verbal inflection in Dutch dialects. Morphology 16: 291-312.

Bloemhoff, Henk

2008 Klank- en vormleer. [Phonological and morphological structure]. In: Henk Bloemhoff, Jurjen van der Kooi, Hermann Niebaum and Siemon Reker (eds.), Handboek Nedersaksische Taal-en Letterkunde, 65-113. Assen: Van Gorcum.

Boyce Hendriks, Jennifer

1998 Immigration and linguistic change: A socio-historical linguistic study of the effect of German and Southern Dutch immigration on the development of the Northern Dutch vernacular in 16th/17th century Holland. Ph.D. thesis, University of Wisconsin, Madison.

Braune, Wilhelm and Ingo Reiffenstein

2004 [1886] Althochdeutsche Grammatik I. Fifteenth edition.Tübingen: Max Niemeyer Verlag.

Chomsky, Noam

1995 The Minimalist Program. Cambridge, MA: MIT Press.

Devos, Magda

2002 Perifere parallellen. Driemaandelijkse Bladen 54: 45-87.

Draye, Luc

2002 Over de "diftongvrees" van het Meijels [On the fear for Diphthongs in the dialect of Meijel]. Taal en Tongval 13: 63-69.

Endepols, Hubert J

1955 Woordenboek of Diksjenaer van 't Mestreechs [Dictionary of the dialect of Maastricht]. Maastricht: Boosten en Stols.

Goeman, Anton and Johan Taeldeman

1996 Fonologie en morfologie van de Nederlandse dialecten. Een nieuwe materiaalverzameling en twee nieuwe atlasprojecten. [Phonology and morphology of the Dutch dialects. A new data collection and two new atlas projects. Taal en Tongval 48: 38-59.

Goossens, Jan

1956 Stoottoon en diftongering van Wgm. î en û in Limburg [Falling tone and diphthongization of Wgm. î and $\hat{u}$ in Limburg]. Taal en Tongval 8: 99-112.

Gussenhoven, Carlos and Flor Aarts

1999 The dialect of Maastricht. Journal of the International Phonetic Association 29: 155-166.

Harris, John

1994 English sound structure. Oxford: Blackwell.

Harris, John

1997 Licensing inheritance: An integrated theory of neutralisation. Phonology 14: 315-370.

Heeringa, Wilbert

2004 Measuring dialect pronunciation differences using Levenshtein distance. Ph.D. thesis, University of Groningen.

Jongen, René

1972 Rheinische Akzentuierung und sonstige prosodische Erscheinungen. Eine Beschreibung der suprasegmentalen Zeichenformdiakrise in der Moresneter Mundart. Bonn: L. Röhrscheid.

Kats, J. C. P.

1985 Remunjs Waordebook. Roermond: Van der Marck en Zonen.

Ponelis, Fritz A.

1979 Afrikaanse Sintaksis [The syntax of Afrikaans]. Pretoria: Van Schaik. 
Postma, Gertjan

2004 Structurele tendensen in de opkomst van het reflexief pronomen "zich" in het 15deeeuwse Drenthe en de Theorie van Reflexiviteit [Structural tendencies in the genesis of the reflexive pronoun "zich" in 15 th century Drenthe and the theory of reflexivity]. Nederlandse Taalkunde 9: 132-143.

Postma, Gertjan

2012 Language contact and linguistic complexity - the rise of the reflexive pronoun "zich" in a 15 th century Netherlands' border dialect. In: Dianne Jonas and John Whitman (eds.), Grammatical Change: Origins, Nature, Outcomes, 139-159. Oxford: Oxford University Press.

Postma, Gertjan and Pieter van Reenen

2009 De wisselwerking tussen spontane palatalisatie, umlaut en genus [The interaction between spontaneous palatalization, umlaut and gender]. Taal en tongval 18: 109-152.

Reuland, Eric

2001 Primitives of Binding. Linguistic Inquiry 32(3): 439-492.

Reuland, Eric

2009 Taal en Regels; door eenvoud naar inzicht [Language and rules; through simplicity to understanding]. Inaugural Address, University of Utrecht.

Schönfeld, Moritz

1959 Historische Grammatica van het Nederlands [Historical Grammar of Dutch]. (Verzorgd door Adolphe Van Loey). Zutphen: Thieme.

Sloos, Marjoleine and Marc van Oostendorp

2012 The relationship between phonological distance and geographical distance. Umlaut on the diminutive in Dutch dialects. Taal en Tongval 62(2): 204-250.

Swets, Francine

2004 The phonological word in Tilburg Dutch; Government phonology and a city dialect of Dutch. Ph.D. thesis, University of Amsterdam.

Taeldeman, Johan

1990 Ist die belgisch-niederlaendische Staatsgrenze auch eine Dialektgrenze? [Is the border between Belgium and the Netherlands also a border between dialects?] In: Ludger Kremer and Hermann Niebaum (eds.), Grenzdialekte: Studien zur Entwicklung kontinentalwestgermanischer Dialektkontinua, 275-315. Hildesheim/Zuerich/New York: Georg Olms Verlag.

Taeldeman, Johan

2007 De opbouw van het AN: meer zuidelijke dan oostelijke impulsen. [The structure of General Dutch: more impulses from the South than from the East]. Tijdschrift voor Nederlandse Taal- \& Letterkunde 123: 97-107.

Van Bree, Cor

1987 Historische grammatica van het Nederlands [Historical grammar of Dutch]. Dordrecht: Foris.

Van Loey, Adolphe

1969 Middelnederlandse Spraakkunst; I: Vormleer [Middle Dutch Grammar I: Morphology] [6e druk]. Groningen: Wolters-Noordhoff.

Van der Horst, Joop

2008 Geschiedenis van de Nederlandse syntaxis [History of the Dutch Syntax]. Leuven: Leuven University Press.

Van der Sijs, Nicoline

2004 Taal als mensenwerk; Het ontstaan van het $A B N$ [Language as human labour; the genesis of Standard Dutch]. Den Haag: sdu.

Van der Wal, Marijke

1992 Dialect and standard language in the past: the rise of Dutch standard language in the sixteenth and seventeenth centuries. In: J. van Leuvensteijn and Jan Berns (eds.), Dialect 
and standard language in the English, Dutch, German, and Norwegian language areas, 119129. Amsterdam: KNAW.

Van de Velde, Hans

1996 Variatie en verandering in het gesproken Standaard Nederlands [Variation and change in spoken Standard Dutch]. Ph.D. thesis, University of Nijmegen.

Weijnen, Antonius A.

1966 Nederlandse Dialectkunde [Dutch Dialectology]. Second edition. Assen: Van Gorcum.

Hans Bennis, Amsterdam (The Netherlands)

Ben Hermans, Amsterdam (The Netherlands)

\section{Dialectometry}

1. Introduction

2. Literature survey

3. Recent work: Techniques using edit distance

4. Problems, lacunas, prospects, desiderata

5. Atlases

6. References

\section{Introduction}

We discuss quantitative work on Dutch dialectology, a line of work that is often referred to as 'dialectometry'. It is worth emphasizing that a great deal of both the Dutch dialectometric work and also work on other languages and dialects has been inspired by the wish to overcome problems in the traditional methodology of dialectology, which has focused on the geographic distributions of single linguistic features (Nerbonne 2009). Examples are two isogloss maps of Weijnen which were published in 1941 (based on 45 isoglosses) and 1958 (based on another set of 18 isoglosses) and the isogloss map of Goossens which appeared in 1970. The three maps suggest different classifications since the choice of the isoglosses differs per map. Isogloss maps are verifiable, but the motivation for the selection of the isoglosses remains unclear. Goossens (1977) mentioned that the isogloss method cannot be applied without making subjective choices. The dialectometric strategy has been to seek more satisfying characterizations by aggregating over a large number of linguistic features. The aggregating step is inevitably quantitative, which has allowed the introduction of powerful quantitative techniques into dialectology.

\section{Literature survey}

\subsection{Categorical measurements: Background}

\section{Séguy}

The first to develop a method of measuring dialect distances was Jean Séguy, assisted and inspired by Henri Guiter. Jean Séguy was director of the Atlas linguistique de la 